\title{
GLACIAL HISTORY OF KOLAHOI GLACIER, KASHMIR, INDIA
}

\author{
By N. Ahmad and N. H. Hashimi \\ (Department of Geology, Muslim University, Aligarh, India)
}

\begin{abstract}
Kolahoi Glacier is one of the longest glaciers in Kashmir and in the past it extended for at least $35 \mathrm{~km}$. In the Pleistocene there were three advances of Kolahoi Glacier and the last one of them was a major advance when the glacier extended as far as Pahalgam.

Résumé. Histoire glaciaire du Kolahoi Glacier, Cachemire, Inde. Le Kolahoi Glacier est l'un des plus longs glaciers du Cachemire et, dans le passé, il s'étendait sur au moins $35 \mathrm{~km}$. Au pléistocène, il y a eu trois avancées du Kolahoi Glacier, la dernière fut une avance importante, lorsque le glacier arrivait jusqu'à
Pahalgam.

Zusammenfassung. Die glaziale Geschichte des Kolahoi Glacier, Kaschmir, Indien. Der Kolahoi Glacier ist einer der längsten Gletscher Kaschmirs; er war früher wenigstens $35 \mathrm{~km}$ lang. Im Pleistozän kam es zu drei Vorstössen des Kolahoi Glacier; der letzte und grösste davon reichte bis Pahalgam.
\end{abstract}

\section{INTRODUCTION}

Kolahoi Glacier lies in lat. $34^{\circ} \mathrm{IO}^{\prime}$ N., long. $75^{\circ} \mathrm{I} 9^{\prime} 30^{\prime \prime}$ E. (Fig. I) and the melt-water stream of Kolahoi Glacier is known as the West Liddar River, which joins the East Liddar River at Pahalgam ( $35 \mathrm{~km}$ from the snout). Pahalgam is connected with Srinagar by a good road and from there a "jeepable" road extends to Aru (i.e. first i I km). Beyond that, the remaining $24 \mathrm{~km}$ to the glacier snout have to be covered either on foot or by pony.

Although Kolahoi Glacier is easily reached and many tourists visit it each year, it did not attract the attention of geologists and it has never been studied in detail. Grinlinton (1928), in his study of East Liddar Glacier, has only suggested that a study of West Liddar and Kolahoi Glaciers would be interesting. Middlemiss (1909, I9Io, I9II) and Wadia (I934, 1953) have studied the stratigraphy of the areas to the north-west, but most probably they did not visit Kolahoi Glacier.

Kolahoi Glacier (Fig. 2) is about $5 \mathrm{~km}$ long and it flows from the north-west of a névé field covering about $35 \mathrm{~km}^{2}$. At one end of this névé field is the north-eastern cirque of Kolahoi Horn. This névé field also feeds three other glaciers. The easternmost of these flows northward and its melt water enters the Sind River (not shown in Fig. I). The other two terminate in the hanging valley glaciers along the eastern wall of Kolahoi Glacier. The cirque on the north-western face of Kolahoi Horn feeds a hanging valley glacier which descends along the southern valley wall and the cirque on the southern face of Kolahoi Horn feeds a glacier which melts before it descends to the Aru Valley.

\section{KoLAHOI VALLEY}

The glaciated section of the Kolahoi valley is semi-circular and about $35 \mathrm{~km}$ long. At its head it has a north-west aspect and at Pahalgam, at its terminus, it faces south-east. Throughout its entire length the width of the valley changes several times. In the initial stages the valley is deep, U-shaped and narrow; in this section the glacier is flowing over basalt. $0.5 \mathrm{~km}$ below the snout the valley widens; here it flows over the shales and limestones of the southern limb of the Basmai Anticline. $3 \mathrm{~km}$ down-stream from the snout the valley crosses a bed of limestone underlain by the Muth Quartzite. This limestone bed forms a riegel and the valley floor drops about ${ }_{5} \mathrm{~m}$ where the West Liddar River descends a waterfall. Above this waterfall the valley is orientated east-west, but below the fall it turns to the south-west and avoids crossing the Muth Quartzites (at the core of the Basmai Anticline). At the waterfall the northern valley wall has two steps cut at 3800 and $3050 \mathrm{~m}$, respectively; both these steps 


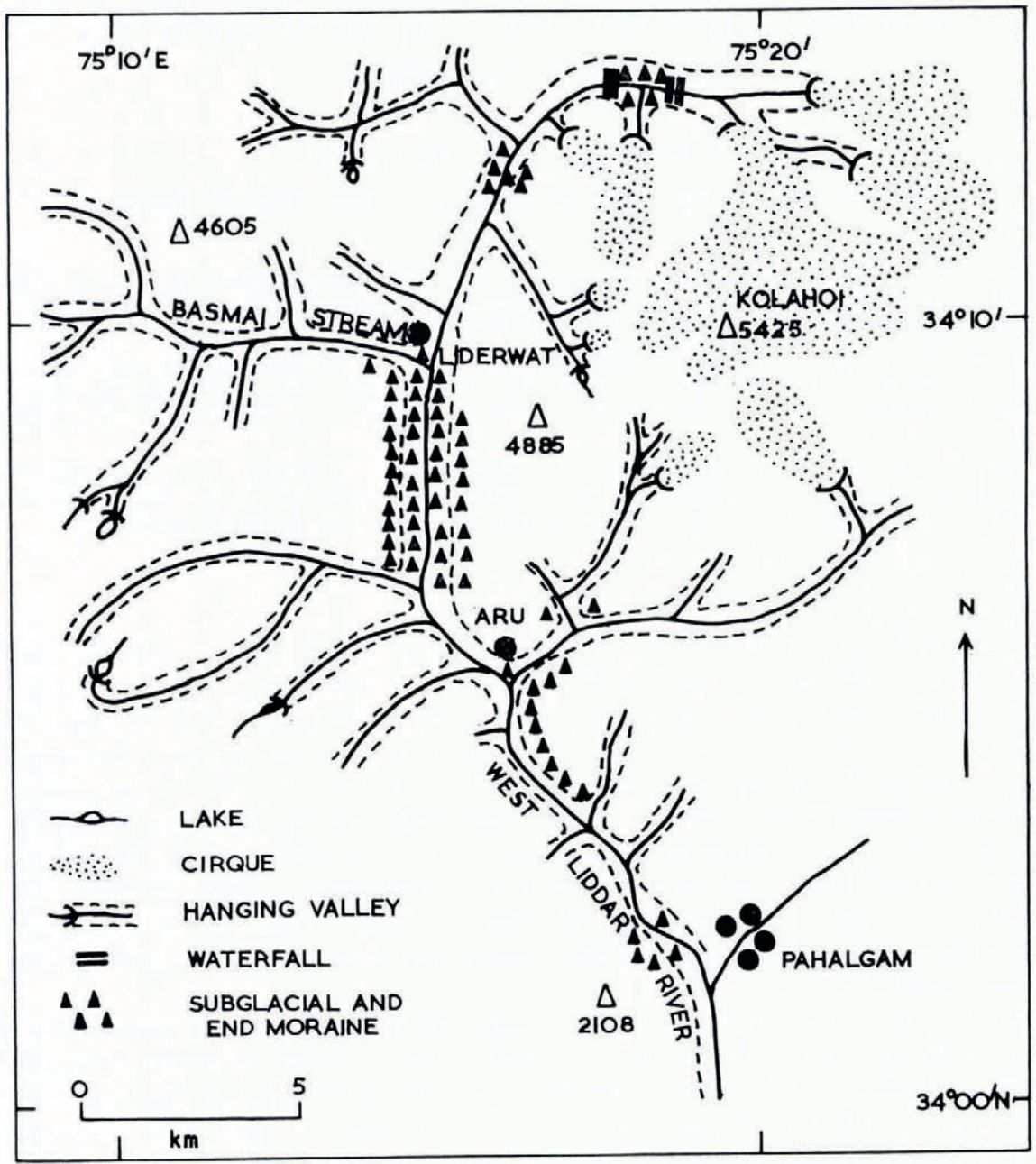

Fig. r. Map of the Kolahoi valley, Kashmir, India.

converge up-stream at the base of the lower hanging valleys in the eastern wall. $2 \mathrm{~km}$ downstream from the waterfall the Basmai Stream joins the West Liddar River and below their confluence the valley cuts through Panjal Traps. Except at Liderwat, Aru and Pahalgam, where the overlying Panjal Traps have been eroded away, the entire length of the valley below this junction is cut on Panjal Traps and narrow. At Liderwat and Aru, the valley is wide and U-shaped. From $2 \mathrm{~km}$ above Pahalgam the valley has a V-shaped notch cut at the base of the U-shaped valley with interlocking spurs (Fig. 3). These spurs are below the level of the Kolahoi subglacial moraines and they have been cut into the bedrock. The base of the $\mathrm{V}$ is level with the East Liddar valley floor.

\section{MORAINES}

The subglacial and lateral moraines cover almost the entire glaciated part of the valley. Near Pahalgam the subglacial moraines are overlain by current-bedded sand and clay layers which are sometimes varved. $0.5 \mathrm{~km}$ above Aru an end moraine crosses the valley and it 


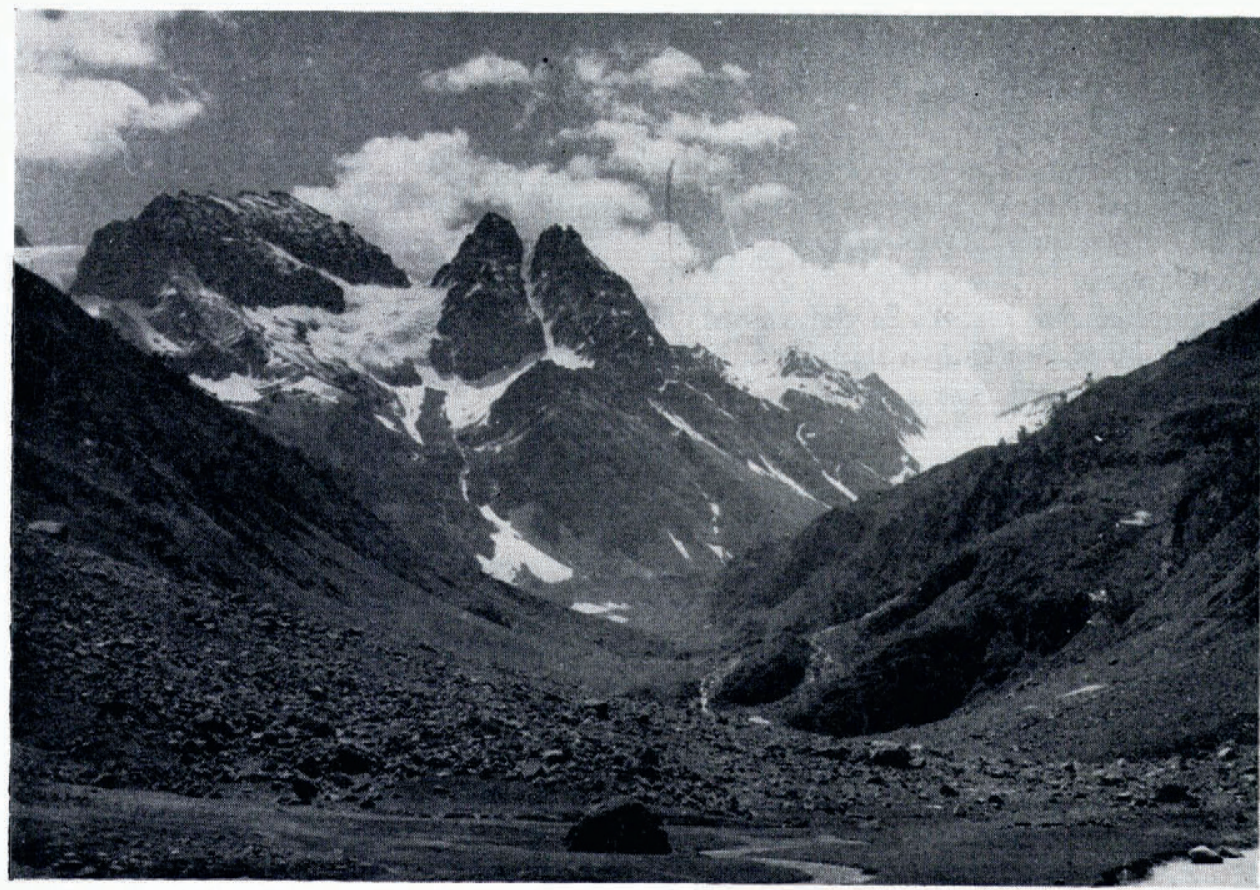

Fig. 2. Kolahoi Glacier and the upper part of the Kolahoi valley, Kashmir.

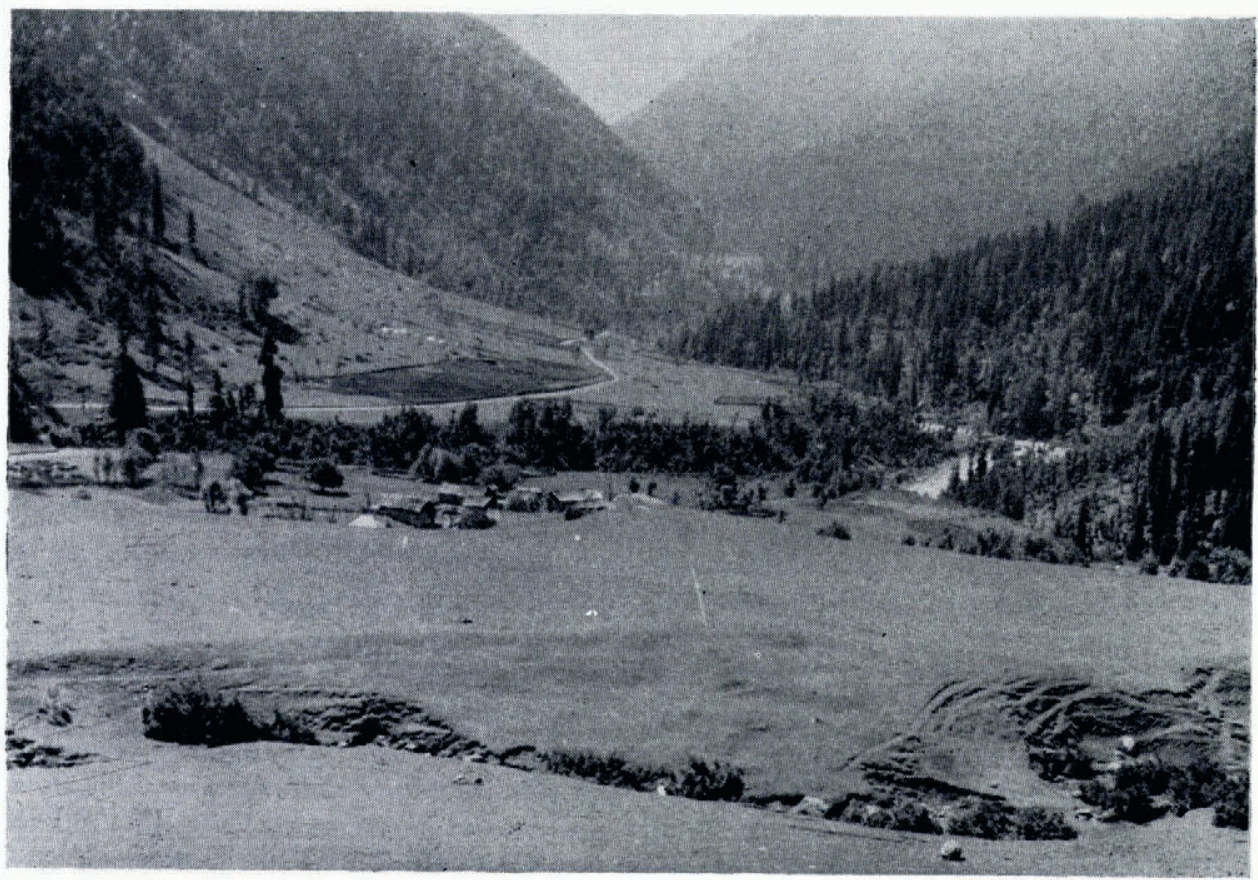

Fig. 3. Interlocking spurs in the West Liddar valley $2 \mathrm{~km}$ above Pahalgam, Kashmir. 
extends towards Liderwat for $6 \mathrm{~km}$. South of the Liderwat Rest House a lateral moraine of Kolahoi Glacier and an end moraine of Tarser Glacier cross the mouth of the Tarser Stream. Just below the Basmai Stream junction there is the beginning of a low end moraine and this extends down-stream for about $0.5 \mathrm{~km}$. Above the Basmai Stream junction an $18 \mathrm{~m}$ high lateral moraine forms a step along the western wall of the valley, and this moraine ends at the lower waterfall. At least nine low morainal ridges cross the valley between the Basmai Stream junction and the snout. The third ridge above the waterfall has blocked the river, forming a lower waterfall.

Between the two waterfalls the valley floor is covered with clayey till across which the stream meanders, but above the upper waterfall the valley floor is covered by an ablation moraine with angular blocks and no clay matrix.

\section{The Pleistogene glaciation}

In the Pleistocene, Kolahoi Glacier had ten tributary glaciers. All but two of these now terminate as hanging valley glaciers. Four of these hanging valley glaciers joined between the glacier snout and the Basmai Stream junction, and the other four joined below Aru. One tributary glacier joined the main glacier from the east at Aru and the other from the west at Liderwat. Aru Glacier was fed by the same névé field as the one which now feeds Kolahoi Glacier and two other smaller névé fields on each side of it. The other glaciers originate at the Tarser Lake cirque and the wide névé field which surrounds it.

During its maximum advance, Kolahoi Glacier possibly extended as far as Pahalgam but it was only for a short time. The interlocking spurs and the V shape of the lower part of the valley near Pahalgam support this view. The moraine which the West Liddar River cuts across as it enters Pahalgam is most probably the lateral moraine of East Liddar Glacier. At this stage West Liddar Glacier joined East Liddar Glacier north of the roughly rochemoutonnée-like nob near the western valley wall, about $30 \mathrm{~m}$ above the present valley floor.

At the end of its maximum advance, the glacier retreated to above Aru where it deposited a continuous end moraine for about $6 \mathrm{~km}$. During this stillstand, sand and clay beds which overlie the subglacial moraines below Aru were deposited. It was also at this time that the $\mathrm{V}$ cut in the valley floor near Pahalgam was initiated.

After the deposition of this end moraine the glacier retreated up-stream very rapidly and stopped at the end of the wide valley near the Basmai Stream junction. Above this junction the glacier retreated slowly and during its short stillstands it deposited the morainal ridges. Above the upper waterfall, the retreat was very slow and so the ablation moraine was deposited. The clayey moraines between the two waterfalls are probably pro-glacial deposits of the meltwater streams.

\section{Conclusion}

During the maximum of glaciation, which was also the third advance when the glacier extended as far as Pahalgam, the stillstand was only for a short time. As the glacier retreated it remained above Aru for a long time. Since this was a small glacier, it also retreated upstream very quickly, whereas the larger Tarser Glacier took a longer time to retreat. Once Tarser Glacier had retreated up its own valley, Kolahoi Glacier slowly retreated up-stream to halt at the Basmai Stream junction. The lateral moraine below the lower waterfall and the end moraine at the Basmai Stream junction were possibly deposited during the halt stage. The two steps in the valley wall above the waterfall suggest that Kolahoi Glacier has experienced at least three advances. Most probably the third was the maximum advance during which all other evidence of earlier advances was removed. 
The lower waterfall possibly developed as a riegel during the third advance because the resistant quartzites above the waterfall could not be eroded as rapidly as the shales below. The hardness of the rock has also controlled the width of the valley, and it could well have been responsible for changes in the direction of the valley.

\section{AcKNOWLedgements}

The authors are grateful to the Wadia Institute of Himalayan Geology, Delhi, for providing the opportunity through financial assistance to study the area. They are also indebted to Professor Fakhruddin Ahmad, Head of the Geology Department, Aligarh Muslim University, Aligarh, and other members of the Department for kind co-operation.

MS. received I August 1973

\section{REFERENCES}

Grinlinton, J. L. 1928. The former glaciation of the East Lidar valley, Kashmir. Memoirs of the Geological Survey of India, Vol. 49, Pt. 2, p. 289-388.

Middlemiss, C. S. 1909. Gondwanas and related marine sedimentary systems of Kashmir. Record of the Geological Survey of India, Vol. 37 , Pt. 4, p. $286-327$.

Middlemiss, C. S. 1910. A revision of the Silurian-Triassic sequence in Kashmir. Record of the Geological Survey of India, Vol. 4o, Pt. 3, p. $206-60$.

Middlemiss, C. S. 1911. Sections in the Pir Panjal range and Sind valley, Kashmir. Record of the Geological Survey of India, Vol. 41, Pt. 2, p. 115-44.

Wadia, D. N. 1934. The Cambrian-Trias sequence of north-western Kashmir (parts of Muzaffarabad and Baramula districts). Record of the Geological Survey of India, Vol. 68, Pt. 2, p. 121-76.

Wadia, D. N. 1953. Geology of India. Third edition. London, Macmillan and Co. Ltd. 